\title{
Achieving The Perfect Work-life Balance Among Businesswomen in Bahrain
}

Habeeb Ur Rahiman, Lecturer, College of Business Administration, Kingdom University, Bahrain Email: habeeb.udy@gmail.com

Dr. Rashmi Kodikal, Research Guide, Visvesvaraya Technological University.

Email: rashmikodikal@gmail.com

\section{ABSTRACT}

Key Words: Work

life balance,

Businesswomen,

Bahrain
Women have achieved great success in penetrating all fields at the social level, businesses, innovations and industries and have been able to compete with men in achieving the top positions in various sectors while maintaining her position as a mother and housewife. (Clark, 2013) Moreover, achieving a balance between work and home management is one of the challenges women face today. The work life balance is really difficult to be managed, especially in the presence of infants who need special care with a lack of cooperation from many employers, a large number of studies conducted on woman's samples from the Middle East and related to the balance between work and home indicated that $37 \%$ of employers support working women to achieve balance between work and home, indicating that 63\% of employers have no desire to cooperate with working women's, thus increasing the difficulties and challenges of achieving balance between work and home life. (Friedman \& Greenhaus, 2014).

\section{INTRODUCTION}

Women working in Bahrain have become active members of the economic development process, through the acquisition of half of the registered businesses in the Ministry of Industry and commerce, as well as a large proportion of employees in the private and public sectors, which leads us to examine the perfect life-balance between work and home and the difficulties and challenges faced by women's in addition to the role of the legislative authority to strike a balance that serves the interests of women and develop their capabilities as an important member of society. (Alam \& Omar, 2011)
Women have achieved great success recently by penetrating all areas and sectors, which pushed them to reach the top leadership positions and achieving strategic balance with working men's. (Mathew \& Panchanatham, 2015) But this success is not without the difficulties and challenges faced by women in achieving the perfect work-life balance. As well as shortcomings in the legislation which support woman's in the workplace by offering more privileges that make them distinctive and successful in running their homes, especially since the basis of society begins with the woman who founded future generations. Bahrain in one of the small Island in middle east having population one and a half million. Unless 
like other countries in the middle east, in Bahrain women's are more independent and working in various sectors either in the service and manufacturing sector. The government of Bahrain in association with various semi-government institution working hard to empower women entrepreneur to participate in various business activities. Among these Tamkeen is one such organization organized series of activities to women to participate in various program and participate and contribute to the socio-economy of Bahrain. As women acted as one of the important contributors to the Bahrain economy having worklife balance is also important issues to be taken care of. In this regard, this study in intends to understand the challenges, issues pertaining worklife balance of businesswomen in Bahrain.

\section{Research Objectives}

1. To determine whether family support affects businesswoman WLB

2. To examine whether related-work overload affects the businesswoman WLB

3. To investigate whether time management affects the businesswoman WLB

\section{Research Hypothesis}

H1:Achieving the perfect work-life balance depending on how the family supports the businesswoman

H2: Achieving the perfect work-life balance depend on good time management and priorities of the businesswoman

H3: Achieving the perfect work-life balance depend on work conditions of the businesswoman

\section{LITERATURE REVIEW}

Clark (2013) defined the businesswoman as a woman who has her own business alone or with some partners and willing to bear administrative tasks, financial and social risks, and other responsibilities related to the business and work by managing the process day by day and the same definitions proportional with the businessmen. Women face many difficulties to achieve a balance between work and family life as a result of their main role in establishing the family and caring for children in addition to their duties towards work, and thus women have serious difficulties in creating balance. (Alam, Jani, \& Omar, 2011) Therefore, the conflict of jobs between the work and the management of family affairs is one of the most important factors that affected women in achieving full success and building their own project, which was confirmed by most of the authors and researchers. (BER, 2011). Among these key factors are the high responsibilities that couples expect from the fact that the wife is the one who manages the internal family affairs along with some external aspects. (Braun, 2011) Therefore, their responsibilities towards the business may be weakened as a result of the divergence of trends and responsibilities imposed on the business owner. Moreover, these difficult factors facing women entrepreneurs make it more advantageous for men to have time to manage their own businesses because they are not distracted and less responsible for the management of family affairs, which is to provide liquidity. 
According to Jahed, Kulsum \& Akthar (2011), one of the most challenging challenges faced by women entrepreneurs is that they have many roles, and they are forced to reconcile these roles, such as their professional role and their responsibilities at home as a wife. Moreover, she must communicate with her husband and manage the family affairs as well as the mother role in taking care of the children. Besides, home keeping affairs, as well as pay attention to her, so that she can complete the process of giving to achieve the work-life balance. Mathew \& Panchanatham (2009) It is found from the journals and kinds of literature that the same issues common among different societies, especially the challenges of creating a work-life balance between men and women but the degree of difference are vast, where the amount of obligations with the men's is much lower than women's and the detailed affairs in the family among the responsibilities of women. Furthermore, raising children and the process of supporting, promoting the physical and social intelligence of the children's from infancy to adulthood among the responsibilities of the wife's with a small percentage of the husbands. These precise details of responsibilities help us to identify the kind of women responsibilities in the management of family affairs.

\section{RESEARCH METHODOLOGY}

The methodology is presented in this chapter and includes the methods, techniques were used to build the research project as well as describing and interpreting the strategies, procedures were used for the data collection, spastically tools and the conceptual research model.

The researcher used two sources for the collection of data by using the "primary and secondary data," as stated by Rabianski, J.S. (2006). The primary data collection aims to survey the population based on the study to obtain accurate data on the current status of the target population by using the quantitative approach.

In this research the descriptive has been used to describe the nature of the study the problem and find logical findings related to the problem of the

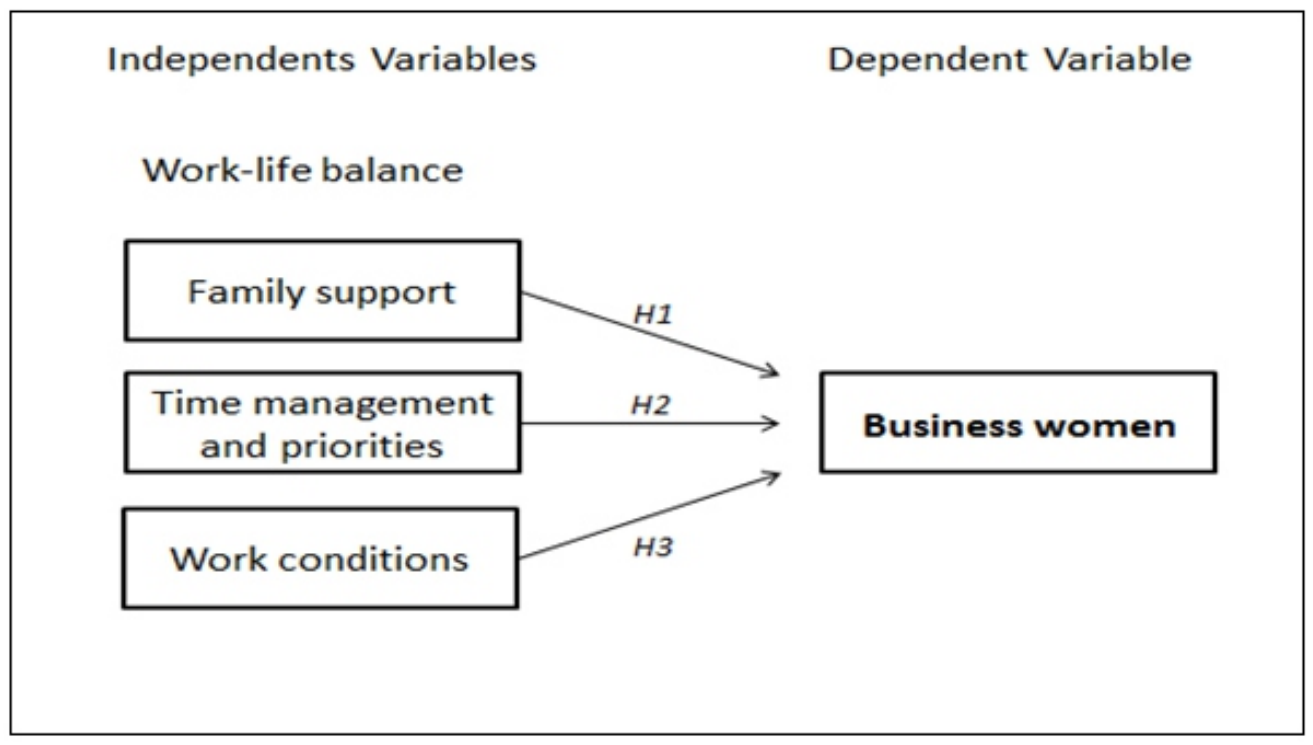

Figure 1. Model of the research 
study and identifying the factors affecting the perfect work-life balance among businesswomen in Bahrain.

\section{RESEARCH FRAMEWORK}

The research framework indicates phenomena that explain many cases and variables about the existing knowledge within a specific boundary and assumptions. The following framework supports the statement of the problems and the research objectives in finding a deep knowledge of the research study.

\section{RESEARCH METHODOLOGY}

Cronbach's alpha was used to test validity and internal consistency of study instruments. Then, the study used means and standard deviation to descriptive sample data. Finally, the hypotheses tests depended on One Sample T-Test.

\section{Sample Responses:}

First, we are going to explore sample responses that respondents answered on the section's questions, using Means, Standard Deviations and sorted in descending. The results were as shown at the following since:

\section{Reliability and Internal Consistency:}

The reliability test was carried out on the constructs identified for this research the list of which is provided in Tables (8). The table provides the figures for Cronbach's alpha for the sample responses derived from SPSS version 20. Table (8) indicates that Cronbach's alpha for the questionnaire's constructs exceed 0.7 with the minimum being 0.702 and maximum being 0.833 , as well as all questionnaires' Cronbach's alpha value was 0.898 . Thus, it can be said that the internal consistency of the items was achieved and the data are reliable.

Table (1) - Reliability and Internal consistency - main sample

\begin{tabular}{|c|c|c|c|}
\hline Construct & No. of questions & Items & Cronbach's alpha (Reliability measure) \\
\hline $\begin{array}{c}\text { Organizational Factors affecting Work Life } \\
\text { Balance }\end{array}$ & 7 & Q1 - Q7 & 0.710 \\
\hline Personal Factors Affecting Work Life Balance & 8 & Q8 - Q15 & 0.702 \\
\hline Effect of work performance on Work Life Balance & 7 & Q16 - Q22 & 0.801 \\
\hline Impact of family and health on Work Life Balance & 8 & Q23 - Q30 & 0.833 \\
\hline
\end{tabular}

\section{Data analysis and findings}

Demographic Variable

Table (2) - Frequencies and Percentages for Age categories

\begin{tabular}{|c|c|c|}
\hline Categories & Frequencies & Percent \\
\hline 35-44 Years & 80 & $40 \%$ \\
\hline 25-34 Years & 50 & $25 \%$ \\
\hline Under 24 years & 40 & $20 \%$ \\
\hline 45-54 Years & 20 & $10 \%$ \\
\hline 55 Years and Above & 10 & $5 \%$ \\
\hline Total & $\mathbf{2 0 0}$ & $\mathbf{1 0 0} \%$ \\
\hline
\end{tabular}


Table (2) indicates that the respondents who participated in the survey regarding the age, were mostly (between $35-44$ years) with $40 \%$ of the respondents, then (25-34 years) with $25 \%$, and then (under 24 years) with $20 \%$ of the respondents, followed by (45-54 years) with $10 \%$, and finally the respondents in the category (above 54 years) were only $5 \%$ of the sample.

Table (3) - Frequencies and Percentages for Experience categories

\begin{tabular}{|c|c|c|}
\hline Categories & Frequencies & Percent \\
\hline 11-15 years & 70 & $35 \%$ \\
\hline 16-20 years & 50 & $25 \%$ \\
\hline Under 5 years & 30 & $15 \%$ \\
\hline 6-10 years & 30 & $15 \%$ \\
\hline More than 20 years & 20 & $10 \%$ \\
\hline Total & $\mathbf{2 0 0}$ & $\mathbf{1 0 0} \%$ \\
\hline
\end{tabular}

Table (3) indicates that the respondents who years) with $25 \%$ of the respondents, then equally participated in the survey regarding the number of both (under 5 years) and (6-10 years) with 15\%, experience's years, in the first-place have (11-15 and finally (more than 20 years) represent only years) with $35 \%$ of the respondents, then (16-20 $10 \%$ of the respondents.

Table (4) - Frequencies and Percentages for marital status categories

\begin{tabular}{|c|c|c|}
\hline Categories & Frequencies & Percent \\
\hline Married & 120 & $60 \%$ \\
\hline Unmarried & 70 & $35 \%$ \\
\hline Divorced & 10 & $5 \%$ \\
\hline Total & $\mathbf{2 0 0}$ & $\mathbf{1 0 0 \%}$ \\
\hline
\end{tabular}

Table (4) indicates that the respondents who respondents, then single with $35 \%$ of the participated in the survey regarding the marital respondents, followed finally by divorced with status, were mostly married with $60 \%$ of the only $5 \%$.

Table (5) - Frequencies and Percentages for type of family categories

\begin{tabular}{|c|c|c|}
\hline Categories & Frequencies & Percent \\
\hline Joint & 120 & $60 \%$ \\
\hline Nuclear & 70 & $35 \%$ \\
\hline Total & $\mathbf{2 0 0}$ & $\mathbf{1 0 0} \%$ \\
\hline
\end{tabular}

Table (5) indicates that the respondents who respondents, then nuclear family with $10 \%$ of the participated in the survey regarding the type of respondents. family, were mostly joint family with $90 \%$ of the

Table (6) - Frequencies and Percentages for number of dependent categories

\begin{tabular}{|c|c|c|}
\hline Categories & Frequencies & Percent \\
\hline Two & 80 & $40 \%$ \\
\hline None & 50 & $25 \%$ \\
\hline Three & 50 & $25 \%$ \\
\hline One & 20 & $10 \%$ \\
\hline Total & $\mathbf{2 0 0}$ & $\mathbf{1 0 0} \%$ \\
\hline
\end{tabular}


Table (6) indicates that the respondents who participated in the survey regarding the number of dependent, were mostly have two with $40 \%$ of the respondents, then equally who have none dependents and who have three with $25 \%$ of the respondents, followed finally by the participants who have only one dependent with $10 \%$.

Table (7) - Frequencies and Percentages for designation categories

\begin{tabular}{|c|c|c|}
\hline Categories & Frequencies & Percent \\
\hline Private Employee & 90 & $45 \%$ \\
\hline Government Employee & 80 & $40 \%$ \\
\hline Business Owner & 30 & $15 \%$ \\
\hline Total & $\mathbf{2 0 0}$ & $\mathbf{1 0 0 \%}$ \\
\hline
\end{tabular}

Table (7) indicates that the respondents who with $45 \%$ of the respondents, then government participated in the survey regarding the employee with $40 \%$ of the respondents, and finally designation, were working as a private employee business owners with only $15 \%$.

\section{Organizational Factors affecting Work Life Balance:}

Table (8) - Frequencies for Organizational Factors

\begin{tabular}{|l|c|c|}
\hline \multicolumn{1}{|c|}{ Question } & Mean & Std \\
\hline I have a well-defined task to be performed & 4.85 & 0.48 \\
\hline I have deadline to be met at work & 4.60 & 0.80 \\
\hline There is autonomy in doing working and decision making & 4.20 & 0.75 \\
\hline I get assistance and help form peers when needed & 3.90 & 0.70 \\
\hline I have to spend more time for work than official working hours & 3.60 & 0.97 \\
\hline my work timing fixed & 2.95 & 0.81 \\
\hline I am supported and guided by your superior & 2.85 & 0.73 \\
\hline \multicolumn{1}{|c|}{ Total Section } & $\mathbf{3 . 8 5}$ & $\mathbf{0 . 6 1}$ \\
\hline
\end{tabular}

Table (8) indicated that the general mean of the section was (3.85), since at the first place was "I have a well-defined task to be performed" with mean equals to (4.85), followed by "I have a deadline to be met at work" with mean equals to (4.60), then "There is autonomy in doing working and decision making" with mean equals to (4.20), as well as "I get assistance and help form peers when needed" with mean equals to (3.90), followed by "I have to spend more time on work than official working hours" with mean equals to (3.60), then "my work timing fixed" with mean equals to (2.95), and finally "I'm supported and guided by your superior" with mean equals to (2.85). 
Personal Factors Affecting Work Life Balance:

Table (9) - Frequencies for Personal Factors

\begin{tabular}{|l|c|c|}
\hline \multicolumn{1}{|c|}{ Question } & Mean & Std \\
\hline I interact with family members after work daily & 4.25 & 0.54 \\
\hline Conflict with family affects the work & 4.00 & 0.95 \\
\hline I attend my work responsibility on phone/computer when at home & 3.85 & 0.48 \\
\hline I am late at work due to family responsibilities & 3.80 & 0.51 \\
\hline I miss family and social functions due to work commitments & 3.75 & 0.43 \\
\hline I carry my work at home & 3.65 & 1.02 \\
\hline I attend family calls on work & 3.60 & 0.74 \\
\hline Due to personal and family responsibilities I cannot concentrate on work & 3.59 & 0.80 \\
\hline \multicolumn{1}{|c|}{ Total Section } & $\mathbf{3 . 8 1}$ & $\mathbf{0 . 3 3}$ \\
\hline
\end{tabular}

Table (9) indicated that the general mean of the section was (3.81), since at the first place was "I interact with family members after work daily" with mean equals to (4.25), followed by "Conflict with family affects the work" with mean equals to (4), then "I attend my work responsibility on phone/computer when at home" with mean equals to (3.85), as well as "I'm late at work due to family responsibilities" with mean equals to (3.80), followed by "I miss family and social functions due to work commitments" with mean equals to (3.75), then "I carry my work at home" with mean equals to (3.65), as well as "I attend family calls on work" with mean equals to (3.60), and finally "Due to personal and family responsibilities I cannot concentrate on work" with mean equals to (3.59).

\section{Work Performance Affecting Work Life Balance:}

Table (10) - Frequencies for Work Performance

\begin{tabular}{|l|c|c|}
\hline \multicolumn{1}{|c|}{ Question } & Mean & Std \\
\hline I can carry multiple task without much pressure & 4.50 & 0.59 \\
\hline I am punctual at work & 4.40 & 0.66 \\
\hline I have cordial relations with peers or colleagues & 4.38 & 0.69 \\
\hline I get opportunities for career growth & 4.15 & 0.48 \\
\hline My performance at work is appreciated by superiors & 3.75 & 0.62 \\
\hline I meet my deadline of work & 3.60 & 0.97 \\
\hline I take initiatives at work Total Section & 3.35 & 0.91 \\
\hline & $\mathbf{4 . 0 2}$ & $\mathbf{0 . 4 3}$ \\
\hline
\end{tabular}

Table (10) indicated that the general mean of the section was (4.02), since at the first place was "I can carry multiple tasks without much pressure" with mean equals to (4.50), followed by "I'm punctual at work" with mean equals to (4.40), then "I have cordial relations with peers or colleagues" with mean equals to (4.38), as well as "I get opportunities for career growth" with mean equals to (4.15), followed by "My performance at work is appreciated by superiors" with mean equals to (3.75), then "I meet my deadline of work" with mean equals to (3.60), and finally "I take initiatives at work" with mean equals to (3.35). 


\section{Family and health Affecting Work Life Balance:}

Table (11) - Frequencies for Family and health

\begin{tabular}{|l|c|c|}
\hline \multicolumn{1}{|c|}{ Question } & Mean & Std \\
\hline I get time to develop my hobbies & 4.05 & 0.92 \\
\hline I'm able to socialize & 4.00 & 0.84 \\
\hline I'm able to get proper sleep(6 to 8 hrs daily) & 3.80 & 0.68 \\
\hline I experience conflict with children/Parents & 3.65 & 0.86 \\
\hline I take my meals on time & 3.60 & 0.86 \\
\hline I exercise or practice yoga meditation etc & 3.50 & 0.87 \\
\hline I experience conflict with my spouse & 3.35 & 0.97 \\
\hline I go for vacations & 3.25 & 0.94 \\
\hline \multicolumn{1}{|c|}{ Total Section } & $\mathbf{3 . 6 5}$ & $\mathbf{0 . 4 6}$ \\
\hline
\end{tabular}

Table (11) indicated that the general mean of the section was (3.65), since at the first place was "I get time to develop my hobbies" with mean equals to (4.05), followed by "I'm able to socialize" with mean equals to (4), then "I'm able to get proper sleep (6 to $8 \mathrm{hrs}$. daily)" with mean equals to (3.80), as well as "I experience conflict with

\section{Testing of Hypothesis}

Hypothesis 1: Organizational Factors affecting Work Life Balance of the businesswoman.

To test the hypotheses, we have employed one sample T-test to measure the trend of respondents
children/Parents" with mean equals to (3.65), followed by "I take my meals on time" with mean equals to (3.60), then "I exercise or practice yoga meditation etc." with mean equals to (3.50), as well as "I experience conflict with my spouse" with mean equals to (3.35), and finally "I go for vacations" with mean equals to (3.25).

'agreement and to know whether the mean of section (i.e. 3.85) is significantly bigger than the neutral value which is 3 and it is moving towards agreement, the result as follows:

\begin{tabular}{|c|c|c|c|c|c|}
\hline \multicolumn{7}{|c|}{ Table (12) - One-Sample Test } \\
\hline \multicolumn{7}{|c|}{ Test Value = 3 } \\
\hline $\mathbf{t}$ & df & $\begin{array}{c}\text { Sig. (2- } \\
\text { tailed) }\end{array}$ & $\begin{array}{c}\text { Mean } \\
\text { Difference }\end{array}$ & $\begin{array}{c}\text { 95\% Confidence Interval } \\
\text { of the Difference }\end{array}$ \\
\hline & & & & Lower & Upper \\
\hline 19.595 & 199 & .000 & .85000 & .7645 & .9335 \\
\hline
\end{tabular}

Table (12) indicated that Test p-value was 0.00 which is lesser than 0.05 reported that there is a clear agreement on the impact of the family support on the work-life balance of the businesswoman, so, the relationship is significant and the hypotheses aforementioned is accepted, as we state that organizational Factors affecting work-life balance of the businesswoman.

\section{Hypothesis 2: Personal Factors affecting Work}

\section{Life Balance of the businesswoman.}

To test the hypotheses, we have employed one sample T-test to measure the trend of respondents' agreement and to know whether the mean of section (i.e. 3.81) is significantly bigger than the neutral value which is 3 and it is moving towards agreement, the result as follows: 


\begin{tabular}{|c|c|c|c|c|c|}
\hline \multicolumn{7}{|c|}{ Table (13) - One-Sample Test } \\
\hline $\mathbf{t}$ & df & $\begin{array}{c}\text { Sig. (2- } \\
\text { tailed) }\end{array}$ & $\begin{array}{c}\text { Mean } \\
\text { Difference }\end{array}$ & $\begin{array}{c}\text { 95\% Confidence Interval } \\
\text { of the Difference }\end{array}$ \\
\hline & & & & Lower & Upper \\
\hline 34.781 & 199 & .000 & .81250 & .7664 & .8586 \\
\hline
\end{tabular}

Table (13) indicated that Test $p$-value was 0.00 which is lesser than 0.05 reported that there is a clearly agreement on the impact of the family support on the work life balance of the businesswoman, so, the relationship is significant and the hypotheses aforementioned is accepted, as we state that personal factors affecting work life balance of the businesswoman.
Hypothesis 3: Work Performance affecting

\section{Work Life Balance of the businesswoman.}

To test the hypotheses, we have employed one sample T-test to measure the trend of respondents' agreement and to know whether the mean of section (i.e. 4.02) is significantly bigger than the neutral value which is 3 and it is moving towards agreement, the result as follows:

\begin{tabular}{|c|c|c|c|c|c|}
\hline \multicolumn{7}{|c|}{ Table (14) - One-Sample Test } \\
\hline $\mathbf{t}$ & df & $\begin{array}{c}\text { Sig. (2- } \\
\text { tailed) }\end{array}$ & $\begin{array}{c}\text { Mean } \\
\text { Difference }\end{array}$ & $\begin{array}{c}\text { 95\% Confidence Interval } \\
\text { of the Difference }\end{array}$ \\
\hline & & & & Lower & Upper \\
\hline 33.385 & 199 & .000 & 1.02143 & .9611 & 1.0818 \\
\hline
\end{tabular}

Table (14) indicated that Test p-value was 0.00 which is lesser than 0.05 reported that there is a clearly agreement on the impact of the family support on the work life balance of the businesswoman, so, the relationship is significant and the hypotheses aforementioned is accepted, as we state that work performance affecting work life balance of the businesswoman.
Hypothesis 4: Family and health affecting Work Life Balance of the businesswoman.

To test the hypotheses, we have employed one sample T-test to measure the trend of respondents' agreement and to know whether the mean of section (i.e. 3.65) is significantly bigger than the neutral value which is 3 and it is moving towards agreement, the result as follows:

\begin{tabular}{|c|c|c|c|c|c|}
\hline \multicolumn{7}{|c|}{ Table (15) - One-Sample Test } \\
\hline $\mathbf{7}$ & df & $\begin{array}{c}\text { Sig. (2- } \\
\text { tailed) }\end{array}$ & $\begin{array}{c}\text { Mean } \\
\text { Difference }\end{array}$ & $\begin{array}{c}\text { 95\% Confidence Interval } \\
\text { of the Difference }\end{array}$ \\
\hline & & & & Lower & Upper \\
\hline 19.994 & 199 & .000 & .65000 & .5859 & .7141 \\
\hline
\end{tabular}

Table (15) indicated that test p-value was 0.00 which is lesser than 0.05 reported that there is a clearly agreement on the impact of the family support on the work life balance of the businesswoman, so, the relationship is significant and the hypotheses aforementioned is accepted, as we state that family and health affecting work life balance of the businesswoman. 


\section{KEY FINDING AND DISCUSSION}

Through the output of statistical data which indicates proof or rejection of the hypotheses of the study, it was found that many factors affect the work of businesswoman in terms of family and society, and creating a balance between work and family life faces many obstacles, despite all these challenges, the participants in the questionnaire demonstrate the strength and rigidity of many of them in facing the challenges of building a balance between work and family life with weak support from the surrounding an environment such as work or family. The study indicates that most of the responses of participating women tend to recognize that there is a great opportunity to strike a balance between work and family life despite the many challenges and obstacles faced by women in the Kingdom of Bahrain. All hypotheses are acceptable, which indicate that family and health affect the creation of a balance between work and home, as well as the personal factors related to the organization such as support, appreciation, incentives and flexibility with women working in the Kingdom of Bahrain.

\section{CONCLUSION}

The review of literature has been investigated on the grounds of why women entrepreneur's people leave the corporate world to enter entrepreneurial exercises. To incorporated adaptability and deal with their work and individual lives, a woman has started their own particular ventures keeping in mind the end goal to improve work-life adjust Women need to work for the advancement of their youngsters by adjusting work and family life. In this focused situation, women are more sure, advanced with entrepreneurial aptitudes and have faith in following the social approach in the workplace. They concentrate more on keeping up compelling correspondence and association with representatives and clients. Since they saw that issues in business or family can influence their execution in either. In this way, a woman handles the issues both sincerely and for all intents and purposes with their passionate knowledge. The lady's business people trust that viable correspondence and relationship working with family and clients can decrease the pressure experienced in both individual and expert lives and helped them to accomplish adjust.

The more prominent association of women in business ventures and work brought about the rise of work-life adjust issues. With a specific end goal to keep up a sound work-life adjust, an individual need to use adaptable timetable amongst work and individual duties. However, the unevenness creates worry among the ladies. This pressure caused because of poor work-life adjust, unfavorable the physical and psychological wellness and causes behavioral changes in a woman. Woman engaged with independent work have a tendency to create adaptable calendars to keep up adjust amongst work and family requests. In this way, they lean toward tele commuting with a specific end goal to invest a reasonable measure of energy for their residential duties. Men have been roused to take up enterprise to look for monetary benefits and ladies decided on business for greater adaptability in both work and family. 


\section{REFERENCE}

1) Alam, S.S., Jani, M.F.M., \& Omar, A.N. (2011). An empirical study of success factors of women entrepreneurs in Southern Region in Malaysia. International Journal of Economics and Finance,

2) BER (2011). Bangladesh Economic Review, Economic Division, Ministry of Finance, Government of the People's the Republic of Bangladesh, Dhaka (In Bengali)

3) Braun P (2011). Endeavor research fellowship, project report, Centre for regional innovation \& competitiveness, University of Ballarat, Vic, Australia.

4) Brizga, D., Peks, L. (2015) "Work Environment Assessment in the aspect of work Psychology Processes" In: (eds.) Engineering of rural development-International scientific conference. Latvia. 2015. p699-704.

5) Clark SC (2013).Work/Family Border Theory: A New Theory of Work/Family Balance. Human Relations 53(6): 747-770.

6) De Vita L., Mari M., Poggesi S. (2012), "Female Entrepreneurship Research:A Classification of Results." MILANO: The McGraw-Hill Companies, ISBN: 978-88-386-9088-4.

7) Friedman, S D and Greenhaus, J H (2014). “Work and family-Allies or enemies? What happens when business professionals confront life choices", New York.

8) Jahed, A.M., Kulsum, U., \& Akthar, S. (2011). Women Entrepreneurship in Bangladesh: A Study on Support Services Available For Its Development and Growth. Global Management Review. 5(3).

9) Kossek E. E. and Ozeki C. 2011. Work-family conflict, policies, and the job-life satisfaction relationship, A review, and directions for organizational behavior-human resources research, Journal of Applied Psychology, Vol.83, pp.139-149.

10) Mari M., Poggesi S., De Vita L. (2016), "Family embeddedness and business performance: Evidence from women-owned firms, "Management Decision.

11) Mari M., Poggesi S., De Vita L., «Female Entrepreneurship in Italy: An Empirical Investigation,» in Diaz C., Brush C., Welter F., Women's Entrepreneurship in Global and Local Contexts, Edward Elgar Publisher.

12) Mathew, R. V., \& Panchanatham, N. (2009). Worklife balance issues among the women entrepreneurs in South India. In K. J. Cherian, \& S. P. A. Mathew (Eds.), Emerging entrepreneurial strategies for self-development and skill development (pp. 46-57).

13) Mathew, R. V., \& Panchanatham, N. (2015). "Influencers and the role in determining the worklife balance of employees working in the information technology sector." KNEES Journal of
Social Science, 1, 17-31.

14) Shanker, T\& Bhatnagar, J. (2010) “Work Life Balance, Employee Engagement, Emotional Consonance/Dissonance \& Turnover Intention" Indian Journal of Industrial Relations. Vol 46 Issue 1 p 74-87.

15) Zou, M. (2015) "Gender, Work Orientation and work satisfaction” Work, employment and society 2015, Vol.29(1) pp.3-22. 
